J. of the Korean Sensors Society

Vol. 18, No. 4 (2009) pp. $251-262$

\title{
바이오센서
}

황교선 · 김상경 · 김태송

\section{Biosensors: a review}

\section{Kyo Seon Hwang, Sang Kyung Kim, and Tae Song Kim}

\begin{abstract}
Biosensors exploit the specific binding between recognition molecule on the biosensor surface and target molecule in analyte and are used in the detection of specific biomolecules such as protein, DNA, cell, virus, etc., with a view towards developing analytical devices. Recently, application field of biosensors have been expanding from diagnosis to biodefense because they can basically serve as high performance devices. This review describes the basic information of biosensors including definition, classification, and operational principle. Moreover, we introduce micro/nano technology-based biosensors with better detection performance than traditional method and their application examples.
\end{abstract}

Key Words : biosensors, biological molecules, micro/nano technology

\section{1. 소개 및 동향}

바이오센서(biosensor)는 1962년 Leland C. Clark이 효소 전극(enzyme electrode)을 이용하여 포도당을 감 지하여 최초의 글루코즈센서를 개발한 이래로 발전을 거듭하고 있고, 현재 다양한 응용 분야를 가지고 있기 때문에 “21세기 블루오션” 중의 하나로 크게 각광받고 있다. 바이오센서는 생화학 반응에 의한 신호를 전기 신호로 바꾸는 소자 ${ }^{[1]}$ 로 물리학·화학·생물학·전자공 학·재료공학 등 과학 전반에 걸친 기술을 필요로 하는 미래형 융합기술(fusion technology)이라고 할 수 있다. 바이오센서의 주요 응용 분야는 의료용, 환경용, 식품 용, 산업용, 군사용, 실험연구용 등이며, 의료용은 현재 가장 많이 이용되고 있는 분야로써 혈당측정용 바이오 센서와 임신진단용 키트가 바이오센서의 성공적인 상 용화 기술로 알려져 있다.

1990 년대 후반 까지만 해도 바이오센서의 연구 개발 및 상용화는 주로 임상적인 수요가 큰 혈당 센서에 집 중 되어 있었으나, 생명기술(BT), 나노기술(NT), 및 정

한국과학기술연구원 나노바이오연구센터(Nano-Bio Research Center, Korea Institute of Science and Technology)

Corresponding author : tskim@microsystem.re.kr, tskim@kist.re.kr (Received: June 25, 2009, Accepted : July 13, 2009)
보기술(IT)의 비약적인 발달로 여러 분야의 특성을 접 목한 센서가 개발되고 있다. 특히, 당뇨병 뿐만 아니라 다양한 질병의 검사, 치료 및 예후 모니터링이 필요한 임상진단 분야에서는 항원-항체의 특이결합 현상을 바 이오센서에 적용한 면역분석 진단기술의 발전으로 발 병 시 치사율이 높은 급성기 질환 및 암 등의 조기 진 단이나 치료 모니터링 및 판정을 용이하게 하였다. 최 근에 들어서 바이오센서 기술은 단순한 생화학적 반응 을 감지하는 목적에 더하여 고속검색(high-throughput screening)과 다중측정 및 다중진단(multiplexing)이라 는 관점에서 많은 연구가 활발히 진행 중이다 ${ }^{[2]}$. 이러 한 관점에서 새로이 주목받는 기술이 DNA 칩 및 단백 질 칩(protein chip)을 모두 포함하는 바이오칩(biochip) 이고, 더욱 세부적으로 미소 유체이송(microfludics) 원 리를 이용한 랩온어칩(lab-on-a-chip), microTAS(micrototal analysis systems) 등이 크게 각광받고 있다 ${ }^{[3-6]}$.

바이오센서는 임상진단 분야 외에도 학교 급식 및 수입 식료품에 대한 검역 등에서 발생하고 있는 위생 상의 문제가 사회적 이슈로 떠오르고 있는 상황에 환 경호르몬과 같은 내분비 교란 물질의 검색이나 검출을 위한 도구로 유용하게 사용되고 있다. 특히, 살모넬라 균, O-157 균과 같은 독성균의 검출, 식품에서의 잔류 농약, 항생제 등 독성화학물질과 관련된 식품 안정성 분석용 바이오센서에 대한 수요 및 개발이 늘고 있다. 
또한, 폭탄 및 생화학 테러 및 생화학전에 대비한 분자 수준의 폭발물 관련 물질(예: TNT) 검출, 신경가스 검 출에 관한 연구도 다양한 방법을 통하여 이루어지고 있 다. 뿐만 아니라, 인간유전체프로젝트(human genome project)의 결과로서 발생하는 막대한 양의 유전정보를 빠르게 해석하기 위한 다양한 분석 방법이 개발되고 있고, 단백체학(proteomics) 연구에서 발굴된 방대한 양의 생체물질의 기능을 분석하는 바이오센서를 개발 하기 위하여 수많은 연구자들이 노력하고 있담]

본 논문에서는 의료, 환경, 식품, 군사 및 연구용으로 그 응용 분야가 매우 다양하고 그 효용가치가 무궁무 진한 바이오센서를 정의하고, 바이오센서의 기본구성 및 신호 변환 원리에 따른 대표적인 바이오센서의 동 작원리를 간략히 설명하고, 최근에 각광받고 있는 기술 과 마이크로/나노기술 기반의 바이오센서 개발 연구 동향을 살펴보도록 하겠다.

\section{2. 바이오 센서의 기본}

\section{1. 정의}

여러 분야에서 유용하게 사용되고 있는 센서(sensor) 는 “측정 대상물로부터 정보를 측정하여 그 측정량을 인식 가능한 신호로 변환시키는 소자"로 정의 할 수 있다. 센서는 자주 트랜스듀서(transducer)와 혼용되어 같은 개념으로 사용되기도 하는데, 엄밀히 말하면 센서 는 트랜스듀서의 하위개념이라고 할 수 있다. 이는 입 력 신호를 다른 신호의 형태로 변환하는 신호 변환 시 스템(transducing system)의 포괄적인 개념에 포함되기 때문이다. 신호 변환 시스템은 입력 신호를 전기 신호 로 변환하는 입력 트랜스듀서(input transducer)와 신호 처리부 및 신호처리부에서 전달되는 전기 신호를 출력 신호로 변환하는 출력 트랜스듀서(output transducer)로 구성되는데(Fig. 1), 입력 신호를 감지하여 변환하는 입 력 트랜스듀서를 센서, 출력 트랜스듀서를 액추에이터 (actuator)라고 할 수 있다. 이러한 센서에 입력되는 에 너지의 형태에 따라서 사용되는 센서의 특성은 매우 다양하다.(Table 1)
Table 1. Energy type of sensor input and their application examples

\begin{tabular}{cc}
\hline 에너지형태 & 센서에 이용되는 특성 예 \\
\hline 역학적 에너지 & 위치, 속도, 가속도, 힘, 압력, 질량 등 \\
열 에너지 & 열, 온도, 열속 등 \\
화학 에너지 & 농도, 산화환원 전위 등 \\
전기 에너지 & 전압, 전류, 저항, 주파수 등 \\
\hline
\end{tabular}

센서는 측정 대상물에 따라 그 응용에 있어서의 센 서 형태(sensor type)가 결정되는데, 예를 들어, 광·온 도·속도·전자기센서는 물리적 현상을 측정하는 센서 이고, 가스·습도센서는 화학적 현상을 측정하는 센서 라고 할 수 있다. 그렇다면 바이오센서는 무엇인가? 정 확한 정의가 되어 있지는 않지만 가장 보편적으로 바 이오센서는 “생물학 적인 측정 대상물로부터 정보를 측정하거나 생물학적 요소를 모방하는 것을 사용하여 사람이 인식 할 수 있는 유용한 신호(주로, 전기적 및 시각적(색, 형광))로 변환해주는 소자 혹은 시스템"이라 고 정의 할 수 있다 ${ }^{[5]}$. 바이오센서 소자 자체의 성능도 중요하지만 응용단계에 있어서는 바이오센서에서 발생 하는 신호를 처리하는 신호처리부(signal processing element)의 역할이 더욱 중요해 진다. 그렇기 때문에 센서와 신호 처리부를 합하여 “센서 시스템”이라고 통 합하여 명명하기도 한다.

\section{2. 기본원리 및 구성}

바이오센서에 대한 이해를 위해서는 바이오센서의 기본적인 원리 및 센서를 구성하고 있는 구성 요소에 대한 이해가 반드시 필요하다. 바이오센서는 샘플 시료 내에 존재 하는 표적 물질(target material) 혹은 표적 분자(target molecule)를 선택적으로 인식 할 수 있는 생체 감지 물질(bioreceptor) 또는 생체 모방 감지 물질 (biomimetic receptor)로 이루어진 생체 분자 인식 층 (biomolecule recognition layer)과 표적 물질과 생체 감지 물질 사이의 특이 결합 시에 발생하는 신호 변화를 전달 하는 신호변환기(transducer)로 구성되어 있다(Fig. 2) ${ }^{[1]}$.

생체 분자 인식 층으로는 효소(enzyme), 항체(anti-

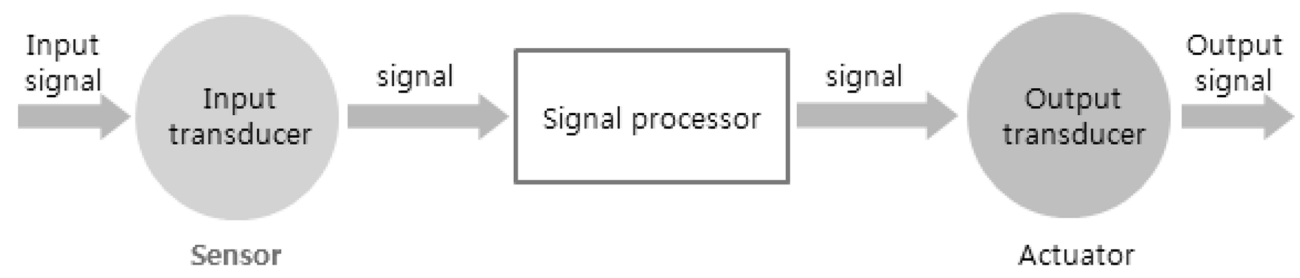

Fig. 1. Schematic diagram of signal transduction system. 


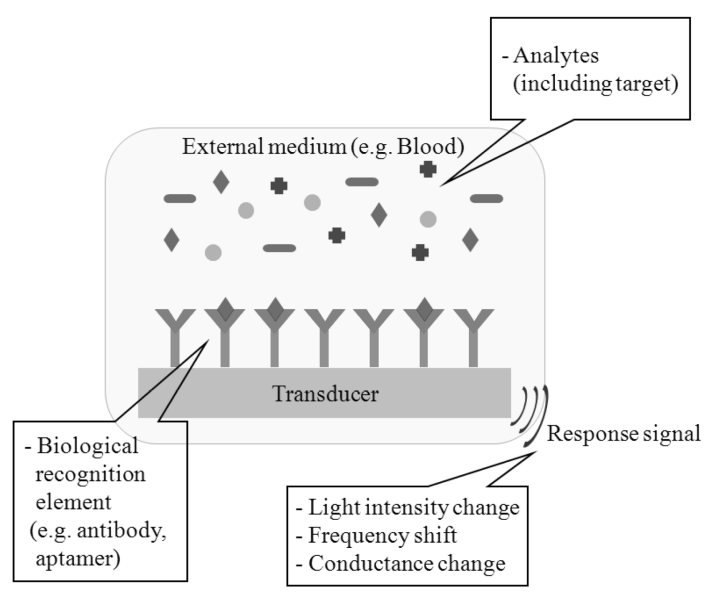

Fig. 2. Schematic diagram of biosensors.

body), 항원(antigen), 멤브레인(membrane)과 같은 단백 질, 조직(tissue), DNA 및 세포(cell)가 사용되고 있으 며, 신호 변환 방법으로는 전기화학(electrochemical), 광학(optical), 기계적(mechanical) 방식 등이 이용된다. 샘플 내에 존재하는 표적 분자가 바이오센서의 생체 분자 인식 층에 생화학적으로 결합하면, 이로 인하여 신호 변환기의 신호에 변화가 발생하게 되고 이를 사 람이 인식 가능한 신호로 변환하여 표적 분자의 정량 및 정성 분석이 가능하게 한다. 바이오센서의 선택성 (selectivity)은 생체 분자 인식 층에 의해 결정되고, 민 감도(sensitivity)는 신호 변환기의 성능에 의해 결정되 기 때문에 센서의 구성 요소를 형성하는 방법은 바이 오센서 개발에 있어서 매우 중요한 것이라 할 수 있다.

\section{3. 분류}

바이오센서의 종류는 측정대상물질(응용분야), 생체 분자 인식 층의 종류 및 신호 변환기의 방식에 따라 매 우 다양하다.

\subsection{1. 측정대상물질(응용분야)에 따른 분류}

응용분야에 따른 분류는 크게 다섯 부분으로 나눌 수 있다. (1) 수요가 월등히 많기 때문에 시장규모가 가장 큰 의료용 분야는 전체 바이오센서 시장의 약 $80 \%$ 를 차지하는 혈당측정용 글루코즈센서(glucose sensor) 뿐 만 아니라, 임신 호르몬, 콜레스테롤, 요소 등과 같은 생체물질을 분석하는 센서가 포함된다. (2) 생화학 테러 및 대량 살상용 무기로 사용될 수 있는 사 린, 탄저균 등을 감지 할 수 있는 바이오센서는 군사용 으로 사용되고 있다. 실제 전장에서 빠른 시간 내에 분 석이 가능해야하고 공기 중에 극미량으로 존재하는 표
적물질을 감지해야 하므로 초고감도를 갖는 소형화 센 서 시스템의 개발이 요구 된다. (3) 환경 호르몬, 중금 속, 농약 등과 같은 환경 관련 물질을 검출하는데 사용 되는 바이오센서이다. 현재 기형아 발생 등에 큰 영향 을 주고 있는 다이옥신과 같은 각종 환경 호르몬에 선 택성을 가지고 있는 수용체 개발과 더불어 초저농도를 감지할 수 있는 센서의 개발이 활발히 이루어 지고 있 다. (4) 최근에 발생하는 수입 농산물 및 식품에 포함 되어 있는 중금속, 항생제 등과 같은 유해한 물질의 검 출에 사용되는 것으로, 먹거리의 안정성을 검사 및 모 니터링하여 국민의 건강을 보호하는데 이용되고 있다. (5) 연구용으로서 생체물질 특이 결합력, 결합 속도, 및 정량분석 등을 평가 하는 데에 사용된다. 최근에는, 민 감도가 우수한 새로운 플랫폼을 개발하거나 휴대화가 가능한 소형화 시스템 개발에 초점이 맞춰져 있다.

\subsection{2. 생체 분자 인식 층에 따른 분류}

초기에는 글루코즈센서와 같이 주로 효소를 인식 층 으로 사용하여 특이 결합에 의한 전자 전달을 주로 이 용해 왔으나 분자생물학의 급속한 발달로 단일클론 항 체(monoclonal antibody)의 대량 생산이 가능하게 됨에 따라 현재는 많은 경우 항원-항체 혹은 항체-효소 반응 을 이용한 면역분석법이 범용되고 있다. 최근에는, 항 체를 대체할 인식체로서 특별한 구조를 갖는 DNA 혹 은 RNA 가닥으로 표적물질을 인식하기 위한 압타머 (aptamer)에 대한 연구가 급속도로 증진되고 있다. 압 타머는 항체보다 더 오랜 시간 동안 안정성을 유지하 고, 항체보다 그 크기가 작으므로 센서의 표면적 증가 에 따른 민감도 증진을 기대할 수 있고, 센서 표면에 고정하기 위한 과정이 간단하므로 센서 기술과 접목하 는 연구가 활발히 진행 중이다 ${ }^{[8]}$. 이외에도 대량의 정 보를 초고속으로 처리하기 위하여 DNA 칩, 단백질 칩 등과 같은 칩 센서에 대한 개발이 마이크로/나노 기술 이 발전하면서 급속도로 이루어지고 있다.

\subsection{3. 신호 변환기의 방식에 따른 분류}

신호 변환기의 방식에 따른 분류는 크게 세 가지로 나눌 수 있다. (1) 민감도가 우수하여 가장 많이 쓰이 고 있는 방법인 광학 감지법(optical detection method) 은 생물학적인 특이 반응을 광학적인 에너지를 주거나 감지하여 시각적으로 인식 할 수 있도록 색, 형광 신호 로 표현하게 해 준다. (2) 글루코즈센서의 전통적인 방 식으로 대표되는 전기화학적 방식이 있다. 신호를 변환 하는 센서의 표면에서 일어나는 전기화학적 반응은 전 기적인 신호 전달의 매개체가 되는 전자의 이동을 발 
생시켜서 이로 인하여 변화하는 전압 혹은 전류를 모 니터링하여 표적물질을 감지한다. (3) 표적 물질과 생 체 물질 인식 층과의 결합에 의해 센서의 기계적인 성 질이 변하여 감지하는 기계적 방식이 있다. 주로, 표적 물질의 센서 표면 결합에 의해 질량이 증가하여 기계 적 센서의 응답 신호에 변화가 일어나게 되는데, 기계 적 신호는 움직임에 의하여 발생하므로 센서의 구동을 위하여 압력을 가하면 전기적인 힘이 발생하거나 전기 적인 힘에 의하여 물질의 구조변화를 일으키는 압전물 질이 유용하게 사용된다.

\section{3. 신호 변환 방법에 따른 동작원리}

신호 변환기에 따른 분류는 위에서 알아본 바와 같 이 크게 광학, 전기화학, 기계적 방법으로 나눌 수 있 다. 각각의 방법을 대표하는 바이오센서를 소개하고 간 단한 동작원리를 설명하도록 하겠다.

\section{1. 광학적 감지법}

광학적 감지법에 기반 한 바이오센서는 생물학 적인 특이 반응을 색 변화 등과 같이 시각적으로 감지 할 수 있게 하는 모든 방법을 총칭하여 말한다. 이러한 광학 적 감지법에 가장 많이 이용되는 방법은 특정한 파장 에 반응하는 형광물질을 생체물질에 부착하여 그 파장 을 가지고 있는 레이저 등을 조사하여 생체물질의 존 재 여부 및 그 양을 시각적 정보로 획득하게 하는 것이 다. 현재 생명공학분야의 실험 뿐만 아니라 임상용으로 도 가장 널리 쓰이고 있는 ELISA(enzyme-linked immunosorbent immunoassay)와 Bioisite diagnostic incorporated 사의 심근경색 진단 소자 그리고 비표지 방 식의 대표적인 SPR(surface plasmon resonance)을 이 용한 감지 방법 등이 색, 형광 등과 같은 시각적 감지 를 이용한 광학적 감지법이라 할 수 있다.

\subsubsection{Enzyme-linked immunosorbent assay(ELISA)}

항체-효소 결합반응에 의한 면역분석법인 ELISA는 그 미세한 방법의 차이 및 용도에 따라 indirect ELISA, sandwich ELISA, competitive ELISA로 나뉘는데, 가장 범용적인 sandwich ELISA 방법에 대해서 설명하도록 하겠다.

혈액이나 혈청 샘플에 존재 하는 표적물질인 특이 항원을 고감도로 감지하기 위하여 항원에 결합하는 항 체가 고정화되어 있는 ELISA 키트 표면에 분석하고자 하는 샘플을 반응 시키면 항원-항체 반응에 의하여 샘 플 내에 존재하는 항원 중에서 ELISA 키트 표면에 고
정되어 있는 항체의 특이 항원만 결합하게 된다. 이러 한 항원에 특이 결합을 하는 또 다른 항체(이차항체, 항원의 여러 반응 사이트(에피토프, epitope) 중에서 ELISA 키트 표면에 고정되어 있는 항체와 다른 에피 토프를 인식하는 항체)를 반응 시키면 항원과 이차항 체가 특이 결합을 하게 되는데, 이러한 이차 항체에 효 소가 부착되어 있어서 효소의 기작을 하게 하는 물질 을 주입하게 되면 여러 가지 광학에너지가 발생하게 된다. 이러한 광학 에너지를 발색, 자외선 검지기 등으 로 감지하여 항원의 존재 유무를 알게 한다 ${ }^{[9]}$. 최근에 들어서는 이차 항체의 효소 대신에 형광물질을 부착하 여 형광 감지 법을 적용하는 방법이 더욱 많이 쓰이고 있다. 또한, 센서의 민감도를 증진시키기 위하여 나노 입자(nanoparticle) $)^{[10,11]}$ 혹은 양자점(quantum dot) ${ }^{[12]}$ 을 이차항체에 부착하여 사용하기도 한다.

\subsection{2. 심근경색 진단 소자}

본 논문의 마지막 부분에서 소개될 나노기술이 접목 된 바이오센서는 비 침습적 이면서도 병열, 고속, 그리 고 원격진단이 가능한 휴대형(point of care) 개인 진단 시스템의 구현을 가능하게 하는 것이 커다란 장점이라 할 수 있다. Fig. 4는 기존의 멤브레인을 이용한 정성 적인 분석만이 가능한 고속 진단 키트(kit)를 발전시켜 처음으로 마이크로채널(microchannel) 개념을 도입한 Biosite diagnostic incorporated 사의 심근경색 진단 소 자 구성을 내부 모습을 보여주고 있다. 광학적 감지법 을 기본적으로 사용하는 이 심근경색 진단 소자는 오

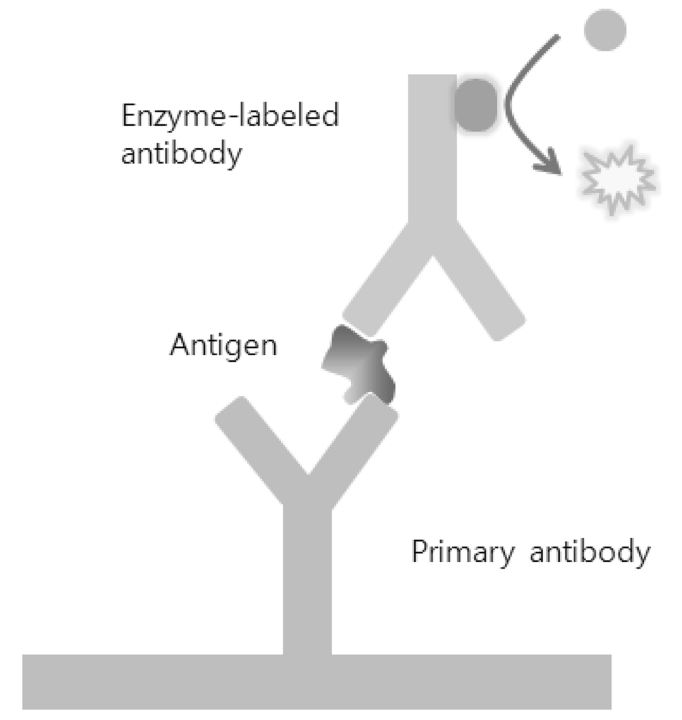

Fig. 3. Schematic digram of sandwich ELISA-based biomolecule detection. 


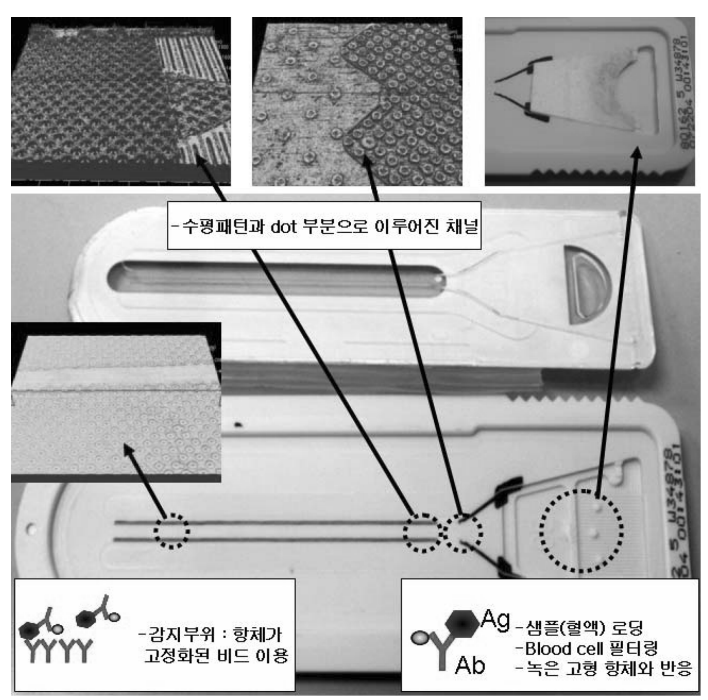

Fig. 4. Myocardial infarctions diagnosis kit of Biosite diagnostic incorporated.

른쪽의 샘플 로딩 부분으로부터 마이크로 채널로 이루 어진 관(capillary)을 따라 샘플이 이동할 수 있도록 되 어 있고 중간에 이들 유체흐름을 조절하기 위한 여러 가지 모양의 채널 게이트가 구성되어 있다. 이 진단 키 트의 핵심은 분석샘플의 재현성 있는 특이 결합을 어 렵게 하는 멤브레인이 없으며 정량분석 시 파이펫 (pipette)과 같은 도구를 이용한 샘플 로딩이 필요 없다 는 점이다. 이것은 흡수성이 없는 플라스틱 재료를 이 용한 마이크로채널을 재현성 있게 제작할 수 있는 MEMS(micro-electro mechanical systems) 기술 덕분으 로 비특이적 반응을 최소화하면서 반응면적을 최대화 하여 측정감도와 반응시간을 단축시켰다. 이 칩은 칩 자체에 파이펫, 유체를 조절하는 이송, 인큐베이션, 분 리, 세척(washing) 기능을 포함한 분석과정 개개의 스텝 을 모두 포함하고 있는 신개념소자라 할 수 있다 ${ }^{[13]}$.

\subsubsection{Surface plasmon resonance(SPR)}

$\mathrm{SPR}$ 은 분석하고자 하는 샘플에 별도의 표지자 표식 없이 분자간의 특이적인 상호반응, 결합량, 친화력, 동 역학적인 요소를 실시간으로 모니터링 할 수 있다. 한 면에 생체 분자 인식 층이 형성 되어 있는 프리즘의 남 은 두 면으로 레이저를 입사하고 반사되는 레이저의 양 을 감지하는 것을 입사 레이저의 입사각을 변화시켜서 반복하게 되면, 표면 플라즈몬 공명(surface plasmon resonance) 현상에 의해 생체 분자 인식 층의 플라즈몬 이 공명하게 되어 입사된 레이저가가 반사되지 않고 그 에너지가 표면을 통해 모두 흡수되게 되는 입사각

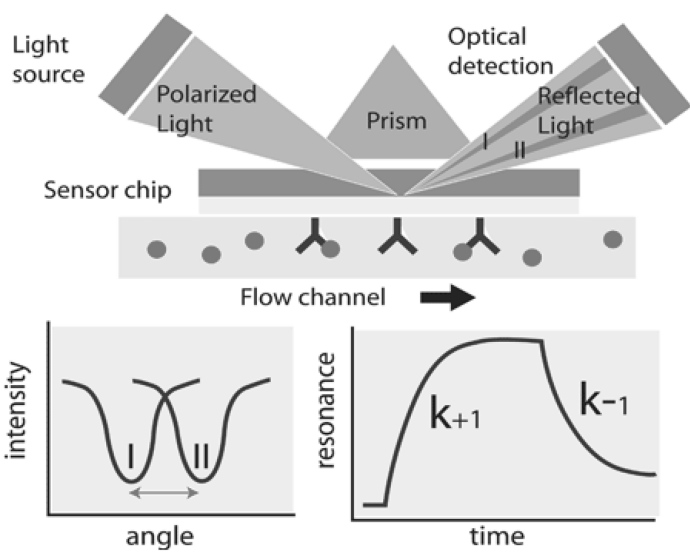

Fig. 5. Schematic diagram of surface plasmon resonance (SPR)-based biomolecule detection(Source: nfs. unipv.it/.../immunology/agabint.html).

이 있게 된다. 이는 프리즘의 생체 분자 인식 층이 형 성되어 있는 금속박막과 유전체의 경계면에 존재하는 표면전자 전하밀도의 진동을 입사레이저가 여기 시키 면서 에너지의 전달이 일어났기 때문이다. 이러한 공명 입사각의 변화를 실시간으로 받아들이는 것에 의해 분 자 간의 반응-결합속도·친화도 등을 측정함으로 최근 각광 받고 있는 기술이다 ${ }^{[14,15]}$.

\section{2. 전기화학적 감지법}

최초의 바이오센서인 글루코즈 센서의 감지 방법이 기도 한 전기화학적 감지법은 역사가 가장 오래 된 생 체물질 감지 방법이다. 센서 표면에서 일어나는 생화학 적 산화-환원 반응에 의하여 전자의 이동이 발생하고, 이러한 전자의 이동에 의하여 전위 차이, 전류 변화 혹 은 전도도 변화가 발생하여 생화학 반응을 전기적 신 호변화로 측정 할 수 있다. 전기적인 감지가 가능함으 로 휴대용을 위한 센서 소형화도 가능하여 오랫동안 각광받고 있다.

\subsection{1. 혈당 센서}

혈당센서는 포도당을 산화시키는 글루코즈 산화효소 (GOD, glucose oxidase)를 폴리아크릴 아마이드(polyacrylamide)의 겔막에 고정화시키고 이 막을 센서 전극 위에 위치하게 하여 만든 최초의 바이오센서를 바탕으 로 현재까지 지속적으로 발전 되어 왔다. 글루코즈센서 에 사용되는 효소인 $\mathrm{GOD}$ 는 공급이 용이하고 다른 효 소보다 $\mathrm{pH}$, 이온강도, 온도에 대해 안정하며 GOD가 글루코즈를 산화시키는 최적조건이 사람 혈액 속의 글 루코즈 농도와 일치하기 때문에 상용화에 있어서 큰 


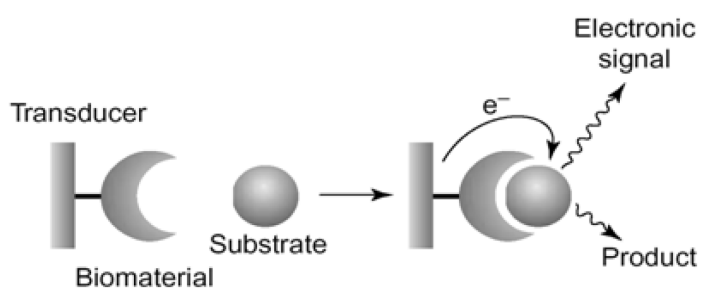

Fig. 6. Basic scheme of electrochemical detection for specific biomolecule analysis.

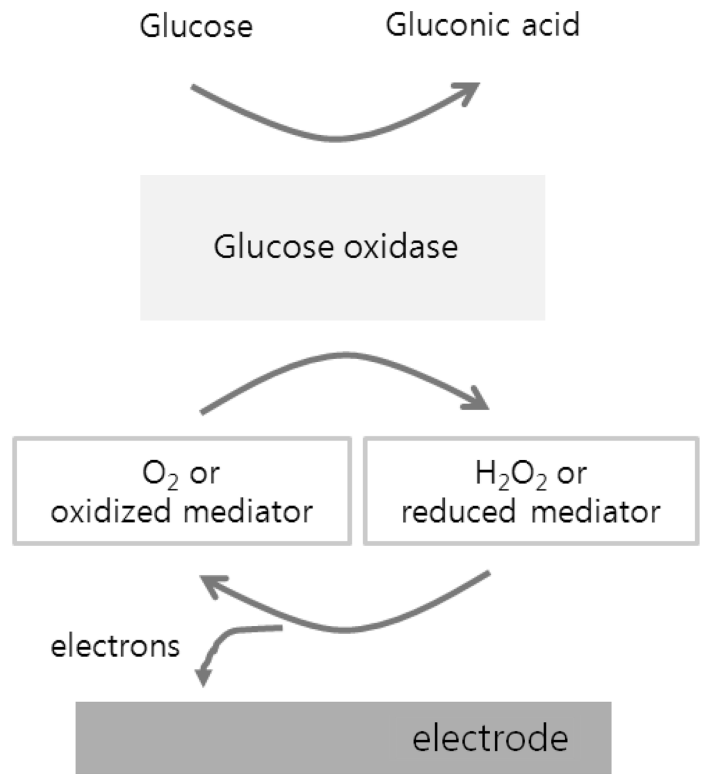

Fig. 7. Operational principle of electrochemical glucose sensor.

의미를 갖을 수 있었다고 할 수 있다.

Fig. 7에서 보는 바와 같이 혈액 내의 글루코즈가 센 서의 멤브레인을 투과하여 고정된 GOD와 반응하면 글루코닉산(gluconic acid)으로 바뀌게 된다. 글루코즈 가 산화될 때 산소 또는 산화된 매개체가 과산화수소 또는 환원된 매개체로 바뀌고 다시 산화되어 원래의 산화된 형태로 되돌아 올 때 발생하는 전자를 전극의 전류를 측정하여 글루코즈를 정량화 한다.

\section{3. 기계적 감지법}

움직임이 없는 센서 표면에서 일어나는 생화학적 반 응을 감지하는 광학적, 전기 화학적 감지법과 다르게 기계적 감지법은 생체 분자 인식 층에서 발생하는 특 이 반응이 센서의 기계적 움직임에 변화를 초래하여 감지하는 방법이다. 센서의 기계적인 움직임에 변화를 주기 위해서는 생체물질간의 특이 결합에 의해 유기되
는 힘에 의해서 결정되는데, 이러한 힘은 표적물질의 질량에 의해 나타난다. 표적 물질이 센서 표면의 생체 분자 인식 층에 결합 되었을 경우 표적 물질의 질량은 기계적으로 구동하는 센서의 움직임을 둔하게 만들어 서 그 움직임의 변화된 정도를 가지고 특정 생체 물질 의 정량 및 정성 분석을 할 수 있게 한다. 이러한 기계 적 바이오센서의 움직임은 측정 가능한 신호로 변환해 서 인지하게 되는데, 주로 쓰이는 방법이 움직임에 의 해 발생하는 음파(acoustic wave)의 주파수 특성을 이 용한 것이다. 그 주파수의 감소 및 증가로 표적물질 양 의 증가 및 감소를 감지 할 수 있다.

\subsubsection{Quartz crystal microbalance(QCM)}

$\mathrm{QCM}$ 은 석영(quartz)의 압전성질을 이용하여 석영 결정(quartz crystal)의 크기, 두께, 탄성도 등과 같은 물 리적인 요소에 결정되는 공진 주파수를 측정하여 석영 결정 표면의 생체 분자 인식 층에 특이 결합하는 표적 물질의 질량을 분석한다 ${ }^{[16]}$.

석영 결정의 양단에 형성 되어있는 전극에 교류전압 을 인가하면 역압전 효과에 의하여 전단모드(shear mode)로 진동하게 되고, 진동수를 주파수분석기로 측 정하여 공진 주파수를 알아내게 된다. 석영결정 표면에 형성 되어 있는 전극 중 하나는 생체 분자 인식 층이

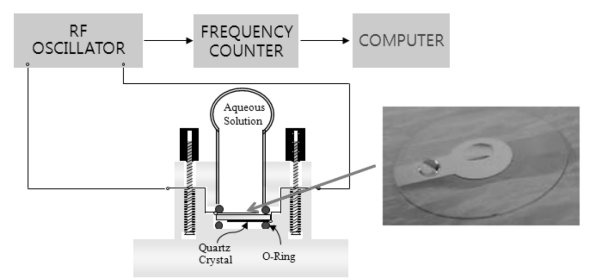

(a)
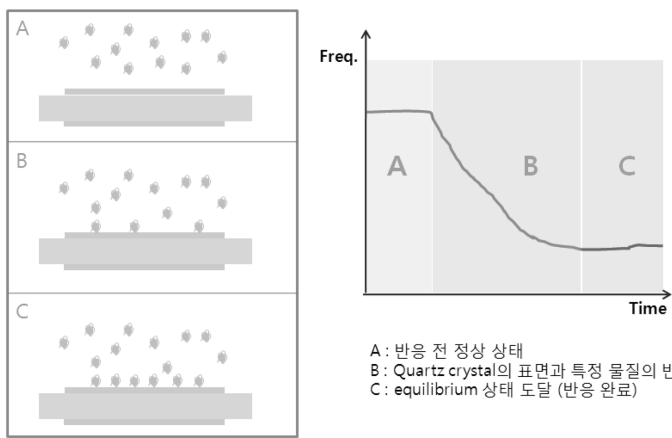

A : 반응 전 정상 상태

$B$ : Quartz crystalof 표면과 특정 물질의 반응 C: equilibrium 상태 도달 (반응 와료)

(b)

Fig. 8. (a) Scheme of quartz crystal microbalance(QCM) system and quartz crystal, (b) detection principle of QCM. 
형성 되어 있고, 이 분자 인식층에 표적 물질이 결합하 였을 때, 석영 결정의 공진 주파수는 감소하게 되고 이 러한 공진 주파수 변화량을 측정하게 되면 Sauerbrey 식 (식 1)에서와 같이 석영 결정의 표면에 결합한 표적 분자의 질량을 계산 할 수 있다.

$$
\Delta f^{\prime} \Delta m=-2 f_{0}^{2} A^{-1}(\rho \mu)^{-1 / 2}
$$

여기서, $\Delta f$ 는 공진 주파수 변화량, $f_{0}$ 는 공진 주파수, $A$ 는 석영 결정 표면의 전극 면적, $\rho$ 는 석영의 밀도, $\mu$ 는 석영의 전단 계수(shear modulus)를 나타낸다.

이 방법은 표적 물질을 정량 분석하는데 사용될 뿐 만 아니라 표적 물질과 인식 분자와의 결합속도 분석 에도 유용하게 쓰일 수 있으므로 크게 주목 받고 있는 방법 중에 하나이다. 하지만, 그 민감도에 있어서 증진 이 필요하기 때문에 센서의 표면적을 넓히는 방법 등 이 개선 방법으로 사용되고 있다 ${ }^{[17,18]}$.

\subsubsection{Surface acoustic wave(SAW) 센서}

탄성체 기판의 표면을 따라 전파되는 음파를 표면 탄성파(surface acoustic wave)라고 한다. 압전 현상에 의해 전기 신호로부터 탄성파가 생성되는데, 탄성파의 전계는 기판 표면 부근에 집중되어, 주파수 특성의 변 화를 모니터링하여 표면 바로 위에 놓인 생체 물질을 감지 할 수 있게 한다 ${ }^{[19]}$.

Fig. 9에서 IDT(interdigital transducer)는 압전체 기 판 상에 형성된 두 개의 빗살형 전극(comb-shaped electrode)이다. 이러한 빗살형 전극(input transducer)에 교류전압이 인가되면 압전체 기판에 동적 변형이 일어 나고, 이는 특성 주파수를 갖는 탄성파를 발생 시킨다. 발생 탄성파의 간섭이 강화되고 동상(in-phase)이 되기 위해서 이웃하는 빗살(finger) 사이의 거리는 탄성파의 반파장과 같아야 한다. 이때 발생된 탄성파의 주파수는 다음과 같이 정의 된다.

$$
f_{0}=\frac{V_{S}}{\lambda}
$$

여기서, $f_{0}$ 는 탄성파의 발진 주파수, $\mathrm{V}_{\mathrm{s}}$ 는 탄성파의 속도, $\lambda$ 는 탄성파의 파장이다. 이 주파수에서 전기 에너

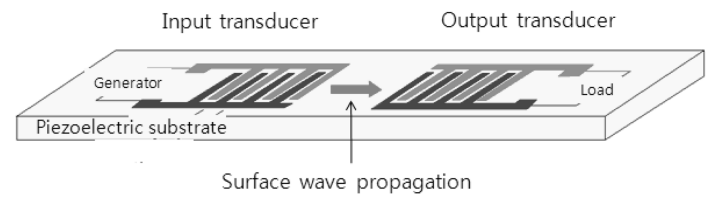

Fig. 9. Schematic diagram of surface acoustic wave(SAW) device.
지를 탄성파 에너지로 혹은 탄성파 에너지를 전기 에너 지로 변환하는 효율이 최대로 된다. 발생된 탄성파는 전극에 수직한 방향으로 진행하고, 전압 인가 IDT(input transducer) 반대편에 위치한 감지 IDT(output transducer) 에 전달되어 탄성파의 주파수 변화를 감지하게 된다 ${ }^{[20]}$. 생체 분자 인식 층이 인가 IDT와 감지 IDT 사이에 형 성되어 있게 되고, 여기에 표적 물질이 특이 결합 하였 을 때 전달되는 탄성파의 속도가 변하여 발진 주파수 에 변화를 초래하게 되며, 이를 이용하여 표적 분자의 질량을 감지 할 수 있다. 뿐만 아니라, 두 전극사이에 위치한 샘플의 점성도 혹은 밀도를 분석하는 데 사용 할 수도 있다.

\section{4. 마이크로/나노 기술 기반의 바이오센서}

단백체학 연구 등을 통해서 질병 관련 단백질의 발 굴 및 생체 대사에 중요한 역할을 하는 호르몬, 신경 전달 물질이 발견되고 있다. 이러한 생체물질은 비교적 고농도 $(\mu \mathrm{g} / \mathrm{ml}$ 수준 $)$ 에서 극 저농도 $(\mathrm{ng} / \mathrm{ml}$ 이하 $)$ 의 농도 레벨까지 다양하게 존재 한다. 특히, 최근 그 중요성 면에서 크게 각광받고 있는 국소의 세포 신호전달을 매개하는 단백질인 시토카인(cytokine) 등과 같은 물질 은 $\mathrm{pg} / \mathrm{ml}$ 범위에서 존재하는 것으로 밝혀졌다 ${ }^{[21]}$. 하지 만, 기존 바이오센서의 기술은 $\mathrm{ng} / \mathrm{ml}$ 이하 수준의 극 저농도를 안정적으로 감지하는 데에 무리가 있다. 이에 따라 고감도 바이오센서에 대한 연구가 필요하게 되었 고, 마이크로/나노 기술은 이를 가능하게 할 기술로 주 목받고 있다 ${ }^{[22,23]}$. 마이크로/나노 기술과 바이오 기술의 접목으로 기존의 바이오센서의 소형화를 하거나 감도 를 향상시키거나 새로운 유형의 바이오센서를 개발하 게 하여 기존 기술로 불가능 하였던 기능을 수행할 것 으로 기대되고 있다. 여기서는 이러한 마이크로/나노 기술 기반의 바이오센서 중 대표적인 네 가지를 소개 하고 그 연구 동향을 알아보도록 하겠다.

\section{1. 나노 와이어 바이오센서}

세계 여러 연구 그룹의 발표된 논문을 통해서 나노 와이어의 전도도 변화를 이용하여 바이오센서로 응용

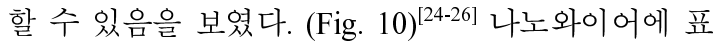
면에 생체 분자 인식 층을 형성 해 놓고 표적 물질을 반응 시켰을 때 나노 와이어 주변에 형성 되는 전하에 의하여 전도도가 변하게 되고 그 변화량을 측정하여 표적물질을 정량분석 할 수 있다. 나노와이어의 구조적 특성 상 반응 할 수 있는 생체 물질 인식 분자의 절대 적 수는 기존의 센서보다 매우 적고, 그 적은 인식 분 


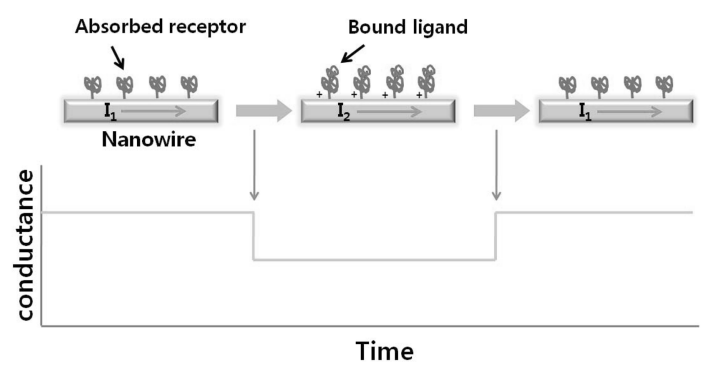

Fig. 10. Schematic diagram of nanowire biosensor-based biomolecule detection.

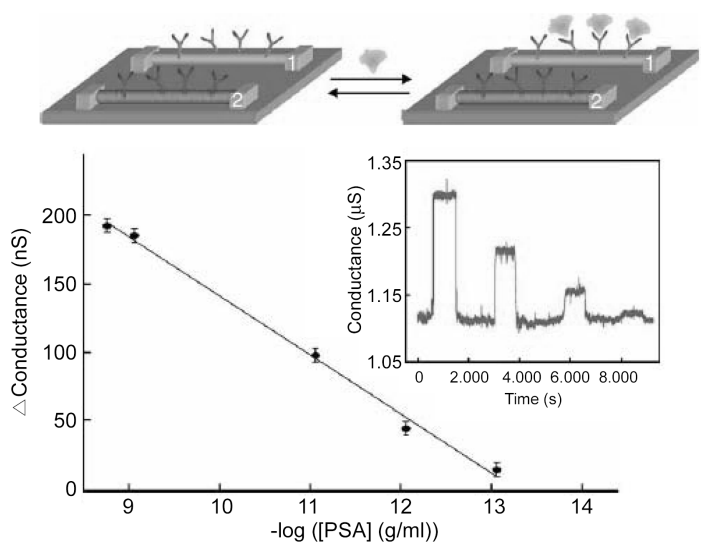

Fig. 11. Example of PSA detection using a nanowire biosensor $^{[26]}$.

자에 표적 물질이 결합하여 감지하는 것으로 표적 물 질의 양이 매우 적어도 나노 와이어의 전도도에 변화 가 생기기 때문에 그 민감도가 우수하다고 할 수 있다.

Harvard 대학의 Lieber 교수팀은 나노 와이어에 항체 를 고정화하고 그 항체에 특이 결합하는 influenza A 바 이러스를 전도도 변화(약 $20 \mathrm{nS})$ 로 검출하였다. 또한, 전 립선 암의 표지 단백질인 PSA(prostate specific antigen) 를 수백 $\mathrm{fg} / \mathrm{ml}$ 범위까지 감지 하였다.(Fig. 11) ${ }^{[27]}$ 이는 임 상용으로 활용 할 수 있음을 보여주는 것이라 할 수 있 으나, 실제 혈액과 같은 샘플에 의한 신호교란 문제 등 은 해결해야 할 과제로 남아 있다. 최근에는 나노와이어 FET(field effect transistor)를 제작하여 생체 물질 특이 결합 시 나노 와이어의 표면에 생성되는 전하에 의한 드 레인 전류 변화로 감지 하는 법이 발표되고 있다[28].

\section{2. 나노 입자를 이용한 바이오센서}

나노 입자는 단독으로 어떠한 생체물질을 감지 하는 데에 이용되기 보다는 기존의 전통적인 방식의 센서 혹은 최근에 개발된 센서의 성능을 증진시키기 위한
것으로 사용된다 ${ }^{[29-33]}$. 기존 광학적 감지 기반의 바이 오센서에 가장 먼저 적용 되었는데, ELISA 방식의 경 우 이차항체에 형광물질을 결합시켜서 그 형광물질을 감지하는 방법에 적용하여 형광물질 대신 형광물질이 농축되어 있는 나노입자를 사용 하여 그 형광 양이 비 약적으로 증가된다 ${ }^{[29]}$. 이러한 신호 증폭을 통해 센서 의 민감도를 높여서 더욱 낮은 농도의 생체 물질 표적 분자를 인식 할 수 있도록 사용 된다. 또한, 암세포의 표면에 특이 반응을 하는 항체를 나노입자에 부착하여 그 나노입자의 존재 유무를 형광 이미지로 판별하여 암세포의 특성을 파악하는데 사용되기도 한다.

Northwestern 대학의 Mirkin 교수 연구팀의 결과에 의하면 나노 입자는 나노와이어 바이오센서에 적용되 기도 하는데 ${ }^{[34]}$, 나노 와이어에 특정한 DNA 염기서열 을 갖는 ssDNA(single-stranded DNA)를 고정화하고 이 $\mathrm{ssDNA}$ 에 상보결합을 하는 염기서열을 갖는 $\mathrm{DNA}$ 를 금 나노 입자에 부착하여 반응 시키면 DNA 간의 상보 결합에 의하여 나노 와이어 상에 금 나노 입자가 배열 하게 된다. 이 때 은 화합물이 용해되어 있는 용액을 반응 시키면 환원 반응에 의하여 은이 금 나노 입자위 에 석출되게 된다. 이러한 작용은 두 전극 사이에 위치 한 나노 와이어 자체의 저항보다 전자가 움직일 수 있 는 은에 의하여 저항이 감소하게 되고 이 원리 이용하 여 특정 생체 분자를 감지 할 수 있게 된다.(Fig. 12) 하 지만, 은 석출 처리 방법의 조건 확립에 있어서 사용하 는 환원제의 산성도가 높음으로 단백질 감지에 사용 될 때는 제한을 받는 것이 단점으로 지적된다.

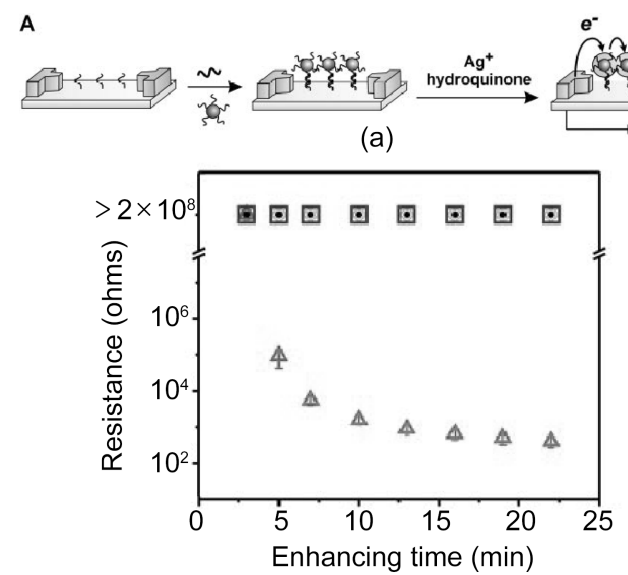

(b)

Fig. 12. Mirkin et al. reported performance improvement of biosensor using nanoparticles (a) Operational scheme, (b) resistance variance of nanowire biosensor by silver enhancing on the gold nanoparticles ${ }^{[34]}$. 


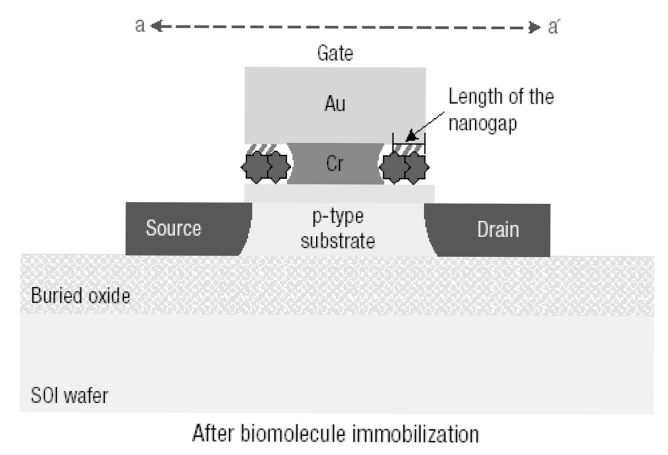

(a)

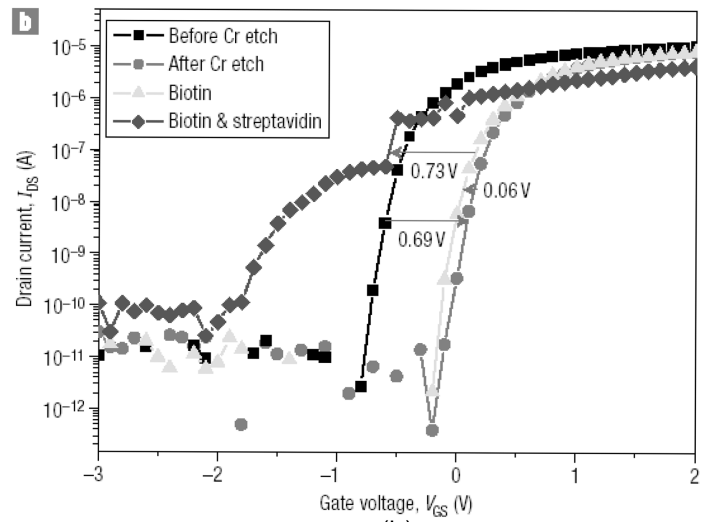

(b)

Fig. 13. Choi et al. reported biosensor application of fabricated nanogap (a) operational scheme, (b) drain current change by protein interaction ${ }^{[36]}$.

\section{3. 나노 갭 바이오센서}

나노 갭 바이오센서는 나노 미터 수준의 갭(gap)을 만들고 그 곳에 일어나는 생물학적 반응을 전기적인 신호 변화로 감지하는 방법이다 ${ }^{[35,36]}$. 이러한 방법은 그 민감도가 매우 우수할 것으로 기대 되는 방법이지 만 수 수십 나노미터의 갭을 형성하여 재현성 있는 소 자를 제작하기가 매우 어렵고 나노 갭에서 면역반응과 같은 생체 결합 반응을 위한 표면처리 기술의 적용이 극히 제한되어 있는 등 여러 가지 기술적 제한 사항이 있기 때문에 아직 기술 개발 초기 단계이다.

한국과학기술원의 최양규 교수 연구팀은 수십 나노미 터의 나노 갭 사이에서 생체물질의 결합이 발생하여 두 전극 사이의 정전용량 변화로 생체물질을 감지하는 방 법을 발표하였다 ${ }^{[36}$. 아래 그림에서와 같이 두 전극 사이 에 약 $15 \mathrm{~nm}$ 의 미세한 갭이 형성 되어 있고 이러한 미세 갭에서 생체물질의 결합이 발생하였을 때 정전용량 변 화로 FET의 게이트(gate) 전압에 따른 drain 전류 특성이 변화하게 되는 것으로 생체물질을 감지 할 수 있다.
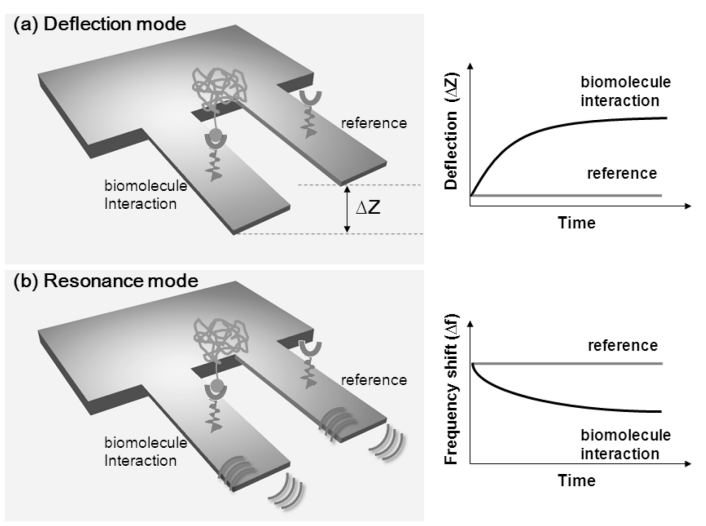

Fig. 14. Operational principle of cantilever biosensor.

\section{4. 마이크로/나노 캔틸레버 바이오센서}

캔틸레버 센서는 외팔보 구조 형상의 민감도가 우수 한 센서로 생체물질 감지막이 형성된 센서 표면에서 특 이 결합이 일어 날 때 발생하는 표면응력과 질량의 변 화에 의하여 센서의 기계적인 특성(휘어짐 혹은 공진주 파수) 변화를 가지고 특이 생체물질을 감지한다 ${ }^{[37-40]}$.

일반적으로, 캔틸레버 센서는 두 가지 모드를 가지 고 생체물질을 감지 할 수 있다. 생체물질 간의 특이 결합이 일어나면서 발생하는 표면응력에 의하여 캔틸 레버 센서의 휘어짐으로 생체물질의 존재를 여부를 알 수 있는 방법(정적모드, static mode)과 구조적 특성에 의 하여 정해지는 공진주파수의 변화로 감지하는 방법(동적 모드, dynamic mode)이 사용된다. 캔틸레버의 표면에 서 생체물질의 결합이 일어 났을 때 생체물질간에 발 생하는 힘이 캔틸레버 센서에 전달되어 새로운 평형상 태(equilibrium state)에 이르기 위하여 변형이 발생하 는데 이러한 변형을 위의 두 가지 방법으로 감지하여 생체물질의 정량적 분석을 하는 것이다.

캔틸레버 바이오센서의 표면에 항체를 고정화하고 샘플 내의 특이 항원을 감지하는 면역반응을 기반으로 정적모드 및 동적모드로 전립선 암의 표지 단백질인 $\mathrm{PSA}$ 를 감지 한 결과가 보고되었다. UC Berkeley 대학 의 Majumdar 교수 연구팀은 정적모드를 이용하여 ${ }^{[41]}$, 한국과학기술연구원의 김태송 박사 연구팀은 동적모드 를 이용하여 ${ }^{[42,43]}$ 캔틸레버 바이오센서의 임상응용 가 능성을 최초로 밝혔다. MIT의 Manalis 교수 연구팀은 캔틸레버 바이오센서로 세포의 무게 변화를 모니터링 하여 세포 상태를 확인하는 방법 $\left.{ }^{[4]}\right]$ 을 제안했다.

마이크로/나노 캔틸레버 바이오센서를 이용한 생체 물질 감지는 비표지 방법이라는 장점이 있지만 정적모 드의 경우 수 나노미터수준의 휘어짐을 측정해야 함으 
로 외력(진동 등)에 매우 민감하고 휘어짐을 측정하는 주된 방법인 레이저의 반사를 이용한 방법은 센서의 표면에 맞춰지는 초점의 위치 및 액체내의 센서표면에 레이저를 조사 하는데에 있어서 발생하는 매질 사이의 굴절률 변화로 인한 빛의 굴절 및 산란 등에도 매우 민 감함으로 재현성에 있어서 한계를 가지고 있다. 이러한 방법을 해결하기 위하여 센서 내에 회로가 집적된 압 저항(piezoresistive) 방법 ${ }^{[4]}$ 을 사용하고 있지만 공정이 매우 어렵다는 단점이 있다. 또한, 동적모드의 경우 진 동 주파수를 측정하기 때문에 외부의 영향은 상대적으 로 적게 받지만 액체 내에서 캔틸레버 센서의 진동에 감쇠(damping) 현상이 일어나기 때문에 출력 신호 변화 에 영향을 지대하게 주고, 액체 내에서 공진주파수 측정 에 있어서 q-factor 감소로 인한 공진 신호의 분해능 저 하를 야기하는 문제를 해결해야 한다. 이러한 액체내의 감쇠 영향을 피하기 위하여 캔틸레버 센서 내에 미세 유로를 형성하여 공진주파수 변화로 생체물질을 감지하 는 방법이 개발되었으나 ${ }^{[44]}$ 그 민감도 면에서 우수한 특 성을 기대하기 어려운 개선 점을 안고 있다. 최근에는, 민감도 증진을 위해서 소자의 물리적인 요소를 변화시 키거나 나노 입자 및 면역반응의 경우 이차 항체를 이 용한 생화학 방법을 사용하여 캔틸레버 공진주파수 변 화를 극대화 하는 방법이 제안 및 사용되고 있다 ${ }^{[46-48]}$.

\section{4. 결 론}

본 논문에서는 바이오센서의 기본적인 내용과 감지 방법에 따른 동작원리 및 최근 각광받고 있는 마이크 로/나노 기술 기반 바이오센서의 연구동향에 대해 소 개하였다. 또한 본 리뷰 논문에서 언급한 방법 외에도 다양한 종류의 바이오센서가 개발 중이거나 상품화가 진행 중이다.

특히 생체분자, 즉 $\mathrm{DNA}$, 단백질, 세포 등에 기반한 생체 분자를 검출하고자하는 바이오센서의 개발을 위 해서는 생체 분자의 추출, 주입, 분리 등의 일련의 전 처리 과정이 요구되며, 최근 크게 각광받고 있는 랩온 어칩(lab-on-a-chip)기술에 기반 하여 그 요소 기술이 크게 발전하고 있다. 또한 전처리 기술로써 생체물질을 농축하는 기술 및 생체 샘플의 전처리에 있어서 탈염 화(desalting) 기술의 개발 또한 요구되고 있다. 이러한 전처리 기술과 센서기술의 결합을 통한 랩온어칩의 구 현이 궁극적인 바이오센서의 향후 발전 방향이 될 것 으로 기대된다.

혈당센서나 임신진단키트와 같이 우리 생활에 보편 화된 바이오센서가 많지 않지만, 온 세계 연구자들은
여러 가지 바이오센서의 상용화 및 보편화를 위해 치 열한 경쟁을 펼치고 있다. 빠른 속도로 발전되고 있는 바이오센서 기술을 볼 때, 몇 년 안에 여러 가지 질병 의 손쉬운 조기 진단, 바이오테러로 부터의 지속적인 안정성 유지, 유비쿼터스 헬스케어 시스템 등이 항상 작동하는 이른 바 “유시티(U-city)”에 살아가기 시작할 지도 모른다. 다양한 학문 분야가 만나서 새로운 고 부 가가치 사업이 만들어 지고 있는 지금 그 시작에 바이 오센서가 서 있고, 이를 위하여 더욱 활발한 연구가 필 요한 시점일 것으로 사료된다.

\section{감사의 글}

본 연구는 지식경제부 21 세기 프론티어 연구개발 사 업인 지능형 마이크로 시스템 연구개발 사업(과제협약 번호 MS-01-113-01)과 한국과학재단 국가핵심연구센 터(과제협약번호 R15-2004-024-00000-0)의 지원을 받 아 수행되었으며 이에 감사드립니다.

\section{참고 문헌}

[1] A. Rasooly, "Biosensor technologies", Methods, vol. 37, pp. 1-3, 2005.

[2] J. Kling, "Moving diagnostics from the bench to the bedside", Nat. Biotechnol., vol. 24, no. 8, pp. 891893, 2006.

[3] H. Craighead, "Future lab-on-a-chip technologies for interrogating individual molecules", Nature, vol. 442, pp. 387-393, 2006.

[4] G.M. Whiteside, "The origins and the future of microfludics", Nature, vol. 442, pp. 368-373, 2006.

[5] R.F. Service, "Coming soon: The pocket DNA sequencer", Science, vol. 282, no. 5388, pp. 399-401, 1998.

[6] M.A. Burns, "Everyone's a (future) chemist", Science, vol. 296, pp. 1818-1819, 2002.

[7] H. Zhu and M. Snyder, "Protein chip technology", Curr. Opin. Chem. Biol., vol. 7, pp. 55-63, 2003.

[8] S. Song, L. Wang, J. Li, J. Zhao, and C. Fan, "Aptamerbased biosensors", Trends in analytical chemistry, vol. 27, no. 2, pp. 108-117, 2008.

[9] S. Venkatasubbarao, "Microarrays-status and prospets", Trends Biotechnol., vol. 22, no. 12, pp. 630637, 2004.

[10] J. Wang. 'Nanomaterial-based amplified transduction of biomolecular interactions", Small, vol. 1, no. 11, pp. 1036-1043, 2005.

[11] J.M. Pingarron, P. Y.-Sedeno, and A.G.-Cortes, "Gold 
nanoparticle-based electrochemical biosensors", Electrochim Acta, vol. 53, pp. 5848-5866, 2008.

[12] M. Grabolle, S. C.-Jaricot, R. Nitschke, U.-Genger, and T. Nann, "Quantum dots versus organic dyes as fluorescent labels", Nature Method, vol. 5, pp. 763 775, 2008.

[13] K.F. Buechler, "Diagnostic devices method and apparatus for the controlled movement of reagents without membranes", US patent Patent No. US 6271040, 2001.

[14] A. Madeira1, E. Öhman, A. Nilsson, B. Sjögren, P. E. Andrén, and P. Svenningsson, "Coupling surface plasmon resonance to mass spectrometry to discover novel protein-protein interactions", Nature protocol, vol. 4, pp. 1023-1038, 2009.

[15] N. Blow, "Proteins and proteomics: life on the surface", Nature method, vol. 6, pp. 389-393, 2009.

[16] S.-I. Kim, H.-J Lee. S.-H. Park, H.-S. Bhang, L.-A. Lee, and S.-J. Choi, "QCM biosensor for the determination of haptoglobin", J. Kor. Sensors Soc., vol. 16, no. 2, pp. 132-141, 2007.

[17] D. Lee, M. Yoo, H. Seo, Y. Taka, W.-G. Kim, K. Yong, S.-W. Rhee, and S. Jeon, "Enhanced mass sensitivity of $\mathrm{ZnO}$ nanorod-grown quartz crystal microbalance", Sens. Actuat. B, vol. 135, pp. 444448, 2009.

[18] H. Seo, M. Yoo, J.-H. Kim, and S. Jeon, "Detection of thrombin-specific oligonucleotides using quartz crystal microbalances coated with silica sol-gel glass thin films", J. Sol-gel Sci. Techn., vol. 46, pp. 33-38, 2008.

[19] K. Lange, B. Rapp, and M. Rapp, "Surface acoustic wave biosensors: a review", Anal Bioanal Chem., vol. 391, no. 5. pp. 1509-1519, 2008.

[20] Y.R. Lim, B.H. Park, S.K. Choi, K.D. Song, and D.D. Lee, "A study on the fabrication of poltmercoated SAW sensors and their sensing properties for some toxic chemical compounds", J. Kor. Sensors Soc., vol. 17, no. 2, pp. 143-146, 2008.

[21] N.L. Anderson and N.G. Anderson. "The human plasma proteome: history, character, and diagnostic prospects", Mol. Cell. Proteomic, vol. 1, pp. 845-867, 2002.

[22] R.C. McGlennen, "Miniaturization technologies for molecular diagnostics", Clin Chem, vol. 47, no. 3, pp. 393-402. 2001.

[23] H.M.E. Azzazy, M.M.H. Mansour, and S.C. Kazmierczak, "Nanodiagnostics: A new frontier for clinical laboratory medicine", Clin Chem, vol. 52, no. 7, pp. 1238-1246, 2006.

[24] K.K. Jain, "Nanotechnology in clinical laboratory diag- nostics", Clin Chim Acta, vol. 358, pp. 37-54, 2005.

[25] K.K. Jain, "Nanodiagnostics: application of nanotechnology in molecular diagnostics", Expert Rev Mol Diagn, vol. 3, pp. 153-161, 2003.

[26] P. Fortina, L.J. Kricka, S. Surrey, and P. Grodzinski, "Nanobiotechnology: the promise and reality of new approaches to molecular recognition", Trends Biotechnol, vol. 23, pp. 168-173, 2005.

[27] G. Zheng, F. Patolsky, Y. Cui, W.U. Wang, and C.M. Lieber, "Multiplexed electrical detection of cancer markers with nanowire sensor arrays", Nat Biotechnol, vol. 23, pp. 1294-1301, 2005.

[28] Y. Chen, X. Wang, M.K. hong, S. Erramilli, and P. mohanty, "Nanoscale field effect transistor for biomolecular signal amplification", Appl. Phys. Lett., vol. 91, 243511, 2007.

[29] S. Weiss, "Fluorescence spectroscopy for single biomolecules", Science, vol. 283, pp. 1676-1683, 1999.

[30] R. Elghanian, J.J. Storhoff, R.C. Mucic, R.L. Letsinger, and C.A. Mirkin, "Selective colorimetric detection of polynucleotides based on the distance-dependent optical properties of gold nanoparticles", Science, vol. 277, pp. 1078-1081, 1997.

[31] J. Liu and Y. Lu, "A colorimetric lead biosensor using DNAzyme-directed assembly of gold nanoparticles", J. Am. Chem. Soc., vol. 125, pp. 66426643, 2003.

[32] T.A. Taton, C.A. Mirkin, and R.L. Letsinger, "Scanometric DNA array detection with nanoparticle probes", Science, vol. 289, pp. 1757-1760, 2000.

[33] J.M. Nam, S.J. Park, and C.A. Mirkin, "Bio-barcodes based on oligonucleotide-modified nanoparticles", J. Am. Chem. Soc., vol. 124, pp. 3820-3821, 2002.

[34] S.J. Park, T.A. Taton, and C.A. Mirkin, "Scanometric DNA array detection with nanoparticle probes", Science, vol. 295, pp. 1503-1506, 2002.

[35] D.S. Kim, J.E. Park, J.K. Shin, P.K. Kim, G. Lim, and S. Shoji, "An extended gate FET-based biosensor integrated with a $\mathrm{Si}$ microfluidic channel for detection of protein complexes", Sens Actuat B, vol. 117, pp. 488-494, 2006.

[36] H. Im, X.-J. Huang, B. Gu, and Y.-K. Choi, "A dielectric-modulated field-effect transistor for biosensing", Nat Nanotechnol. vol. 2, pp. 430- 434, 2007.

[37] P.S. Waggoner and H.G. Craighead, "Micro- and nanomechanical sensors for environmental, chemical, and biological detection", Lab Chip, vol. 7, pp. 1238-1255, 2007.

[38] R. Raiteri, M. Gratarola, H.-J. Butt, and P. Skladal, "Micromechanical cantilevver-based biosensors", Sens 
Actuator B, vol. 79, pp. 115-126, 2001.

[39] K.M. Goeders, J.S. Colton and L.A. Bottomley, "Microcantilevers: sensing chemical interactions via mechanical motion", Chem. Rev. vol. 108, pp. 522542, 2008.

[40] K.S. Hwang, S.-M. Lee, S.K. Kim, J.H. Lee, and T.S. Kim, "Micro-and nanocantilever devices and systems for biomolecule detection", Annual review of analytical chemistry, vol. 2, pp. 77-98, 2009.

[41] G. Wu, R.H. Datar, K.M. Hansen, T. Thundat, R.J. Cote, and A. Majumdar, "Bioassay of prostate-specific antigen(PSA) using microcantilevers", Nat Biotechnol., vol. 19, pp. 856-860, 2001.

[42] K.S. Hwang, J.H. Lee, J. Park, D.S. Yoon, and T.S. Kim, "In-situ quantitative analysis of a prostate-specific antigen(PSA) using a nanomechanical PZT cantilever", Lab Chip, vol. 4, pp. 547-552, 2004.

[43] J.H. Lee, K.S. Hwang, J. Park, K.H. Yoon, D.S. Yoon, and T.S. Kim, "Immunoassay of prostate-specific antigen(PSA) using resonant frequency shift of piezoelectric nanomechanical microcantilever", Biosens. Bioelectron., vol. 20, pp. 2157-2162, 2005.

[44] T.P. Burg, M. Godin, S.M. Knudsen, W. Shen, G.
Carlson, J.S. Foster, K. Bobcock, and S.R. Manalis, "Weighing of biomolecules, single cells and single nanoparticles in fluid", Nature, vol. 446, no. 26, pp. 1066-1069, 2007.

[45] R. Marie, H. Jensenius, J. Thaysen, C.B. Christensen, and A. Boisen, "Adsorption kinetics and mechanical properties of thiol-modified DNA-oligos on gold investigated by microcantilever sensors", Ultramicroscopy, vol. 91, pp. 29-36, 2002.

[46] B. Ilic. Y. Yang, K. Aubin. R. Reichenbach, S. Krylov, and H.G. Craighead, "Enumeration of DNA molecules bound to a nanomechanical oscillator", Nano Lett., vol. 5, pp. 925-929, 2005.

[47] A.K. Gupta, P.R. nair, D. Akin, M.R. Ladisch, S. Broyles, M.A. Alam, and R. Bashir, "Anomalous resonance in a nanomechanical biosensor", Proc. Natl. Acad. Sci. USA, vol. 103, no. 36, pp. 1336213367, 2006.

[48] S.-M. Lee, K.S. Hwang, H-J. yoon, D.S. Yoon, S.K. Kim, Y.-S. Lee, and T.S. Kim, "Sensitivity enhancement of dynamic microcantilever by stress inducer and mass inducer to detect PSA at low picogram level", Lab Chip, In press.

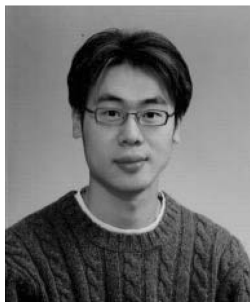

\section{황 교 선}

-2007년 고려대학교 전자컴퓨터공학과(공학 박사)

- 2008년 현재 한국과학기술연구원 나노 바이오센터 연구원

- 주관심분야: 캔틸레버센서, 바이오센서, MEMS/NEMS, 가스센서, 압전체 기반 트랜스듀서, Portable biodevice

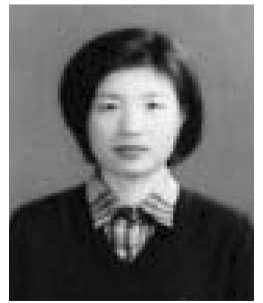

\section{김 상 경}

-2004년 Georjia Institute of Technology 의공학과(공학박사)

- 2005년 현재 한국과학기술연구원 나노 바이오센터 선임연구원

- 주관심분야: 마이크로칩 적용 신물질 공 정, 전기화학센서, 세포조작 및 모니터링, 바이오센서, 바이오센서 표면처리

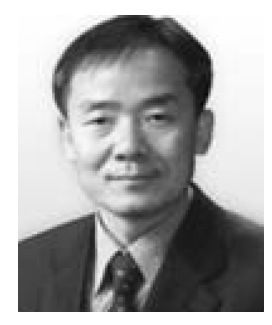

\section{김 태 송}

- 1993년 한국과학기술원 재료공학과(공학 박사)

- 1994년 2000년 한국과학기술연구원 박 막재료연구센터 선임연구원

-2000년 현재 한국과학기술연구원 나노 바이오연구센터 책임연구원

-2004년 현재 지식경제부 21세기 프론티 어연구개발사업 지능형마이크로시스템개 발사업단 단장

- 주관심분야: 캔틸레버센서, 압전체 기반 트랜스듀서, Point of care (POC) system, 인체삽입용 바이오소재 및 소자 